\title{
ANALISIS KERETAKAN PELAT ZONA LAMBUNG KAPAL BERBAHAN FIBER GLASS
}

\author{
Amir Marasabessy ${ }^{1)}$, Saut Siagian ${ }^{2)}$ \\ ${ }^{1)}$ Jurusan Teknik Perkapalan, Fakultas Teknik, Universitas Pembangunan Nasional "Veteran" Jakarta \\ ${ }^{2)}$ Jurusan Teknik Mesin, Fakultas Teknik, Universitas Pembangunan Nasional "Veteran" Jakarta \\ Email: amir141161@gmail.com, sautmarulisiagian@gmail.com
}

\begin{abstract}
Abstrak
Produksi kapal fiber glass di berbagai galangan kapal di Indonesia proses laminasi masih dilakukan secara manual (hand lay-up) di areal terbuka, hal ini sangat rentang terjadi udara terperangkap (air trap) yang dapat menimbulkan lepuh (blistering). Perawatan pitting defect akibat blistering, oleh galangan kapal hanya di sekrap, dibersihkan, didempul, diratakan/ dihaluskan dan gelcoat painting. Tujuan penelitian adalah menyelidiki penyebab kerusakan/ keretakan pelat zona lambung berkaitan dengan blistering. Metode yang digunakan adalah mengamati proses produksi dan pemeliharaan zona lambung kapal fiber glass dan pengujian pelat blistering zona lambung yang dibandingkan dengan pelat asli menggunakan peralatan uji FTIR sesuai standar ASTM E1252-07 dengan metode ATR dan Morphology Analysis. Sesuai pengamatan lapangan, galangan kapal tidak melakukan pengukuran kandungan air diarea blistering yang terdapat pitting defect sehingga terjadi peristiwa osmosis sebagaimana ditunjukan pada spektrum FTIR yakni terjadi penurunan intensitas bilangan gelombang dari gugus puncak $1724 \mathrm{~cm}^{-1} \mathrm{ke} 1722 \mathrm{~cm}^{-1}$ disamping terdapat puncak tambahan pada sampel pelat blister akibat reaksi hidrolisa pada serat penguat, juga terdapat kerusakan yang signifikan pada pelat blistering dan terdapat rongga sehingga menimbulkan kelembaban dalam serat penguat. Dalam waktu (2 s/d 3) tahun serat penguat akan menjadi rapuh/getas sehingga jika terjadi benturan dengan gelombang laut atau objek lain dapat menyebabkann kerusakan/keretakan.
\end{abstract}

Kata Kunci: laminasi, blistering, zona lambung, fiber glass, keretakan

\section{PENDAHULUAN}

\subsection{Latar Belakang}

Kebijakan Pemerintah Indonesia untuk memberdayakan kelompok nelayan diberbagai wilayah di Indonesia yang diwujudkan oleh Kementrian Kelautan dan Perikanan Republik Indonesia melalui program pembangunan 3000 unit kapal ikan berbahan fiber glass dengan berbagai jenis dan ukuran, hal ini selain untuk meningkatkan produksi hasil tangkapan ikan secara nasional juga dapat meningkatkan tarap kehidupan dan kesejahteraan masyarakat kelompok nelayan. Kapal ikan yang diproduksi menggunakan bahan fiber glass memiliki keunggulan teknis dan ekonomis yakni konstruksinya ringan, biaya produksi murah, proses produksi cepat (menggunakan moulded), galangan kapal tidak memerlukan investasi yang besar, teknologinya sederhana, dan tidak memerlukan kualifikasi tenaga kerja yang tinggi[1] sehingga kebutuhannya terus meningkat.

Kapal berbahan fiber glass sering terjadi kecelakaan saat kegiatan pengoperasian, pelat zona lambung di bawah garis air sering mengalami keretakan atau kebocoran saat terjadi benturan (impact) dengan gelombang laut atau dengan objek lain. Hal ini diduga adanya proses produksi dan pemeliharaan/ perawatan kapal secara teknologi dapat dikatakan belum memenuhi faktor teknologi yang baik. Sebagaimana diketahui bahwa kelayak lautan suatu kapal tidak hanya tergantung dari aspek desain, akan tetapi sangat tergantung dari aspek produksi dan perawatan[8]. Proses produksi yang dilakukan diberbagai galangan kapal di Indonesia masih dilakukan secara manual yakni proses pengecoran/laminasi serat penguat fiber glass pada moulded dilakukan dengan menggunakan tangan (hand lay up process) disamping areal produksinya yang terbuka. Dilain pihak galangan kapal sebagai pelaksana pemeliharaan kapal fiber glass hingga saat ini belum melakukan perawatan kapal fiber glass secara baik dan benar, dalam hal ini tidak melakukan pengukuran kelembaban zona lambung di bawah garis air. sehingga tidak diketahui kelembaban serat penguat fiberglass yang dapat mengarah pada kerapuhan. 
Penelitian tentang analisis keretakan pelat kapal yang telah dilakukan adalah analisis keretakan pelat zona lambung kapal patroli fiber glass sebagai akibat adanya laju pertumbuhan tiram laut (Amir Marasabessy, 2014 Dosen Fakultas Teknik Prodi teknik Perkapalan Universitas Pembangunan Nasional "Veteran" Jakarta), selain itu membuat proyek inovasi desain dan produksi kapal patroli Out Board Engine (OBM) 2 × 85 HP (Amir Marasabessy, 2013) yang telah didaftarkan sebagai HKI desain industri dengan nomor pendaftaran: A00201403010, 2014 dan desain kapal ikan sederhana berbahan fiber glass (Amir Marasabessy, 2009) serta metode perawatan yang tepat zona lambung kapal fiber glass di bawah garis air (Amir Marasabessy, 2014).

Metode yang digunakan untuk mengetahui penyebab keretakan pelat zona lambung adalah dengan melakukan pengujian FTIR Microscope (Fourier Transform Infra Red) sesuai standar ASTM E1252-07 dengan metode ATR (Annual Total Reflectance) dan Morphology Analysis terhadap pelat zona lambung bangunan kapal sesuai desain dan blistering (lepuh) untuk mengamati mikro struktur dan gugus puncak intensitas bilangan gelombang serat penguat fiber glass.

Hingga saat ini penelitian tentang keretakan pelat zona lambung kapal fiber glass di bawah garis air belum ada yang meneliti terutama yang berkaitan dengan blistering (lepuh) dan mengingat telah diproduksi kapal ikan fiber glass dalam jumlah yang besar oleh pemerintah serta berkaitan dengan keselamatan jiwa manusia di laut maka hasil dari penelitian

diharapkan akan menjadi pedoman bagi pihak pemilik kapal dan galangan kapal

fiber glass di Indonesia dan khusus kepada pemerintah untuk menerapkan regulasi produksi dan perawatan/pemeliharaan kapal berbahan fiber glass untuk peningkatan mutu dan kualitas guna memperpanjang waktu pengoperasian kapal (Long time ship operation).

\subsection{Tujuan dan Manfaat Penelitian}

Tujuan penelitian menyelidiki penyebab kerusakan/keretakan pelat zona lambung kapal fiber glass di bawah garis air berkaitan dengan proses produksi (laminasi serat penguat fiber glass yang dilakukan secara manual) dan metode pemeliharaan yang tidak tepat.

\section{Manfaat Penelitian:}

a. Sebagai pedoman bagi galangan kapal fiber glass di Indonesia, owners dan owners surveyor untuk peningkatan mutu (kualitas) produksi dan pemeliharaan/ perawatan kapalkapal berbahan fiber glass;

b. Sebagai pedoman bagi pemerintah untuk menerapkan regulasi berkaitan dengan produksi dan pemeliharaan/perawatan kapalkapal fiber glass.

c. Sebagai bahan referensi kapal berbahan fiber glass dilingkungan Fakultas Teknik, program studi teknik perkapalan, teknik mesin serta teknik kelautan dan transpotasi laut.

\section{TINJAUAN PUSTAKA}

\subsection{Roadmap Penelitian}

Roadmap penelitian dimaksud adalah untuk menjelaskan program penelitian yang telah dilakukan sebelumnya yang tentunya terkait dengan kegiatan penelitian yang akan dilakukan dimana dapat dijadikan sebagai bahan referensi/literatur berikut rencana arah penelitian akan dijelaskan secara terperinci sampai dengan pencapaian luaran serta kegiatan peneliti, sebagaimana diperlihat pada gambar 1.

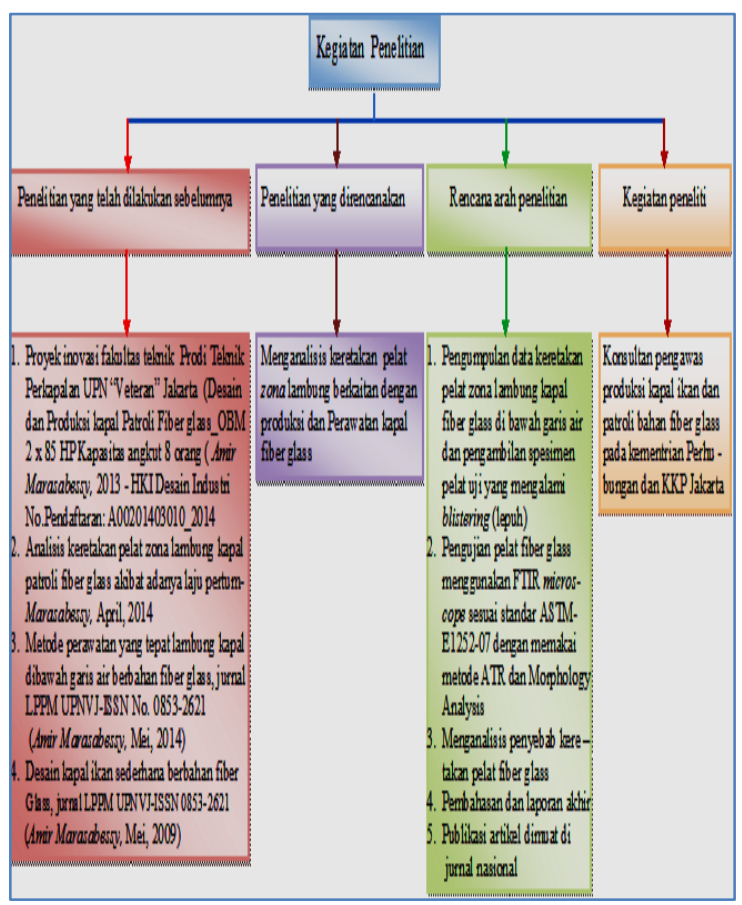

Gambar 1. Roadmap penelitian 


\subsection{Pengertian Fiber glass}

Fiber glass adalah serat gelas yang ditarik menjadi serat tipis dengan garis tengah sekitar $0,005-0,01 \mathrm{~mm}$ sebagaimana yang diperlihatkan pada gambar 2. Serat ini dapat dipintal menjadi benang, yang kemudian diresapi resin sehingga menjadi bahan yang kuat dan tahan karosi untuk dipergunakan dalam pembuatan kapal[9].

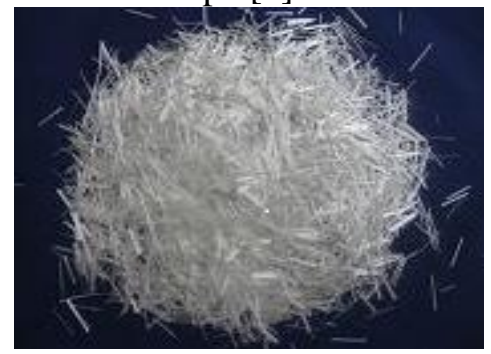

Gambar 2. Serat glass fiber glass

Fiber glass sebagai material komposit[5] merupakan campuran dua atau lebih material penyusun dengan fase berbeda, material penyusun komposit harus mempunyai proporsi jumlah yang jelas dan sifat dari komposit yang terbentuk berbeda dari sifat material penyusunan.

Dalam struktur komposit sesuai gambar 3. terdapat dua atau lebih fase yang dipisahkan oleh lapisan pembatas (inter layer) dalam hal ini adalah resin, lapisan ini penting untuk membedakan material penyusunnya. Material penyusun mempunyai sifat continue dan memiliki jumlah yang lebih besar pada komposit disebut matriks.

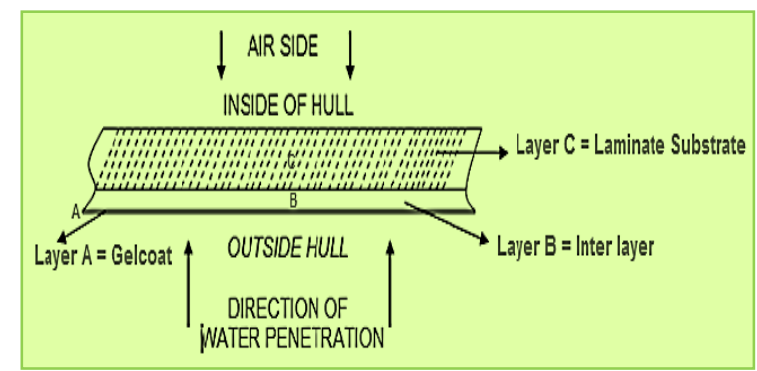

Gambar 3. Struktur komposit fiber glass

Sebuah komposit bisa memiliki matriks dalam bentuk keramik, logam, maupun polimer, sedangkan material penyusun lainnya adalah material penguat (reinforcement) yang bertujuan untuk memperbaiki sifat-sifat mekanik dari matriks. Geometri material penguat merupakan salah satu parameter utama dalam menentukan efektifitas penguatan. Geometri tersebut meliputi konsentrasi penguat, ukuran, tebal lapisan penguat, jarak penyusunan dan orientasinya.
Yang menjadi perhatian pada penguatan komposit fiber glass agar lebih efektif yaitu komponen penguat harus memiliki modulus elastisitas yang lebih tinggi dari pada komponen matriksnya dan harus ada ikatan permukaan yang kuat antara komponen penguat dan matriksnya karena fungsi matriks adalah untuk mendukung dan mengikat reinforcement, mentransfer beban antar reinforcement, dan melindungi reinforcement dari perubahan eksternal.

Arah orientasi serat merupakan hal penting dalam penguatan komposit, karena arah orientasi berkaitan erat dengan penyebaran gaya yang bekerja pada komposit saat terjadi pembebanan mekanis. Distribusi dari serat paling maksimum jika arah serat paralel dengan arah pebebanan. Kekuatan komposit akan berkurang dengan perubahan sudut serat, kekuatan akan melemah jika arah keduanya saling tegak lurus. Terdapat tiga (3) sifat komposit yakni kekuatan parallel dengan serat, kekuatan geser matrik parallel dengan serat, dan kekuatan tegak lurus pada serat.

Karakteristik komposit Fiber glass Reinforced Polyester bergantung dari bermacam faktor diantaranya ikatan antara serat dan matriks, fraksi volume serat, aspek rasio serat, orientasi serat, efisiensi transfer tegangan, dan sifat resin[3]. Karena Fiber glass Reynforced Polyester menggabungkan antara resin yang diperkuat oleh serat, maka sifat komposit yang dihasilkan merupakan sifat gabungan antara sifat resin dan sifat serat penguatnya, seperti yang tampak pada gambar 4.

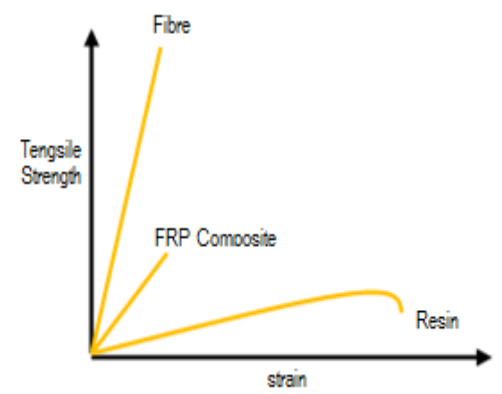

Gambar 4. Ilustrasi deformasi serat, resin dan komposit

\subsection{Bahan Utama Fiber glass}

Bahan utama fiber glass yang digunakan untuk pembuatan kapal dengan type E-glass berupa mirror glaze, gelcoat, choped strand mat, woven roving, resin sebagai media pengikat dan katalis untuk pengering 
sebagaimana yang diperlihatkan pada gambar 5.[2]
Mirror glaze

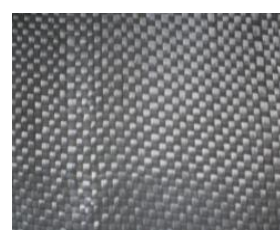

Woven Roving

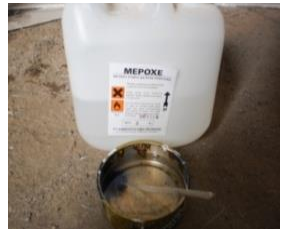

Katalis

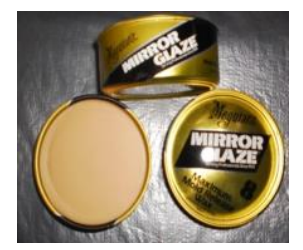

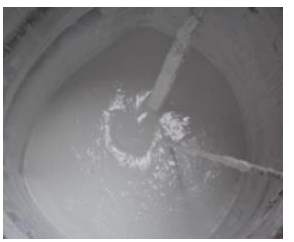

Gelcoat

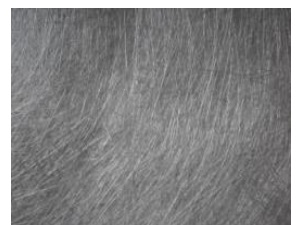

Choped Strand Mat

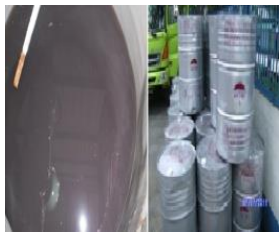

Resin
Gambar 5. Bahan utama fiber glass

\subsection{Pengertian Blistering (lepuh)}

Proses produksi kapal fiber glass yang dilakukan secara manual berupa laminasi serat penguat Mat dan Roving dengan Resin polyester sebagai media pengikat, biasanya menggunakan kuas tangan dan kuas roll bulu dengan areal produksi yang terbuka. Kondisi seperti ini sangat berpeluang terjadinya air trap (udara terperangkap) pada lapisan serat penguat Mat dan Roving, dan ketika produksi kapal selesai hingga kapal dioperasikan maka udara yang terperangkap akan membentuk suatu kelembaban dan semakin lama akan mengumpul membentuk suatu kekuatan dimana kekuatan tersebut suatu saat akan semakin besar yang dapat melebihi kekuatan gelcoat (proses waktu yang lama \pm 3 s/d 4 tahun)[4], sehingga terjadi blistering (lepuh) pada bagian luar gelcoat, sebagaimana diperlihatkan pada gambar 6.[4] sehingga membuat rongga udara yang berpeluang terjadi peristiwa osmosis.
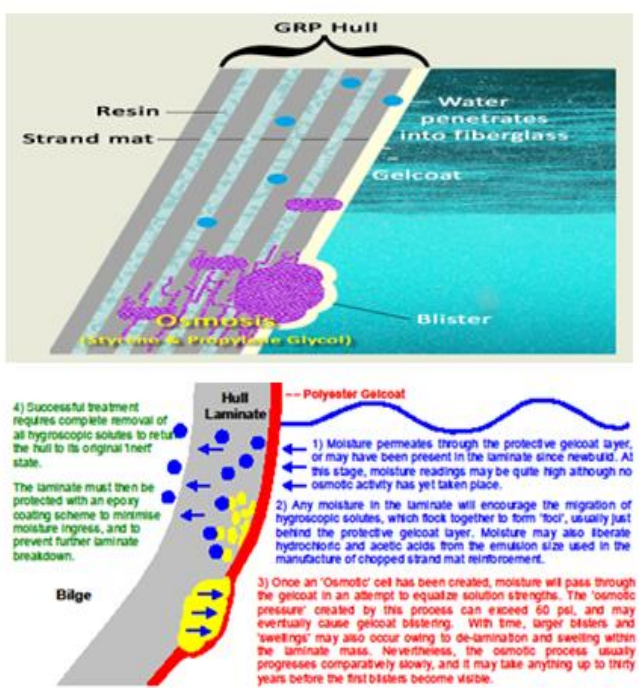

Gambar 6. Peristiwa blistering pada laminasi GRP

\subsection{Peristiwa Osmisis}

Peristiwa osmosis secara umum dapat didefenisikan sebagai suatu kekuatan pergerakan fluida cair untuk menembus lapisan dinding (membrane). Peristiwa osmosis untuk kapal berbahan fiber glass adalah peristiwa dimana terjadi penyerapan air laut kedalam serat fiber glass.[4]

\subsection{Kandungan Air Serat Fiber glass}

Standar ambang batas kandungan air hull fiber glass menurut Badan Klasifikasi Germanischer Loyd adalah $12 \quad \% \quad \mathrm{H}_{2} \mathrm{O}$, sedangkan standar SAMS (Society of Accredited Marine Surveyors), kandungan air hull fiber glass berada pada level $(10-12)$ $\mathrm{H}_{2} \mathrm{O}$.[6]

Alat yang digunakan untuk mengukur kandungan air adalah Electrophisics atau Skipper sebagaimana yang diperlihatkan pada gambar 7[4]. Alat ini ditempelkan pada bagian titik - titik pengukuran yang berpeluang terjadi kelembaban dan hasil pengukuran akan terbaca pada indikator dengan besaran angka dalam bentuk prosentase.
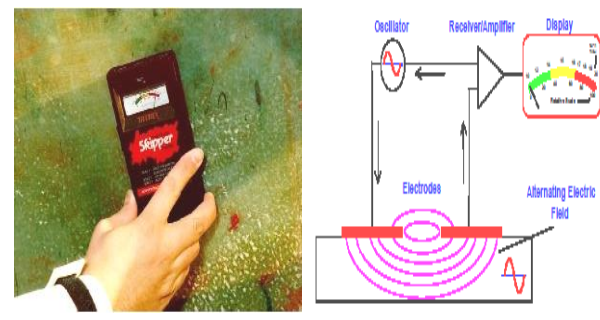

Gambar 7. Alat ukur kelembaban serat fiber glass 


\subsection{Konsep Keretakan}

Konsep keretakan "Jika terjadi kelembaban pada suatu material, dalam waktu tertentu material tersebut akan jadi rapuh sehingga jika terjadi benturan dengan objek lain (impact) dapat menimbulkan keretakan"[7]

Bentuk kerusakan/keretakan zona lambung kapal fiber glass sebagaimana yang diperlihatkan pada gambar 8 .
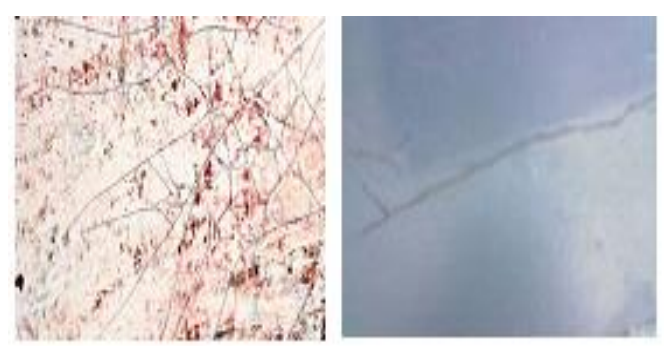

Gambar 8. Bentuk kerusakan/keretakan pelat zona lambung

\section{METODE PENELITIAN}

\subsection{Lokasi Penelitian}

Penelitian dilakukan di galangan kapal fiber glass CV. Cisanggarung Putra Mandiri di Marunda Jakarta Utara sesuai gambar 9, dengan kegiatan usaha dibidang pelayanan jasa produksi bangunan baru dan reparasi kapal berbahan fiber glass.
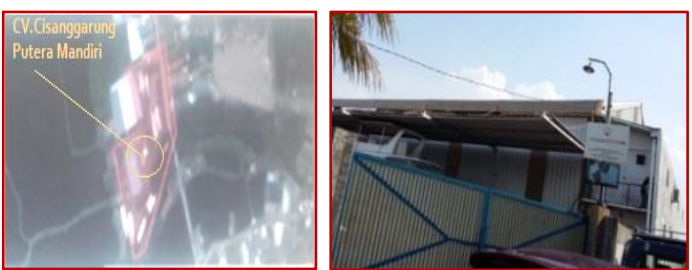

Gambar 9. Lokasi galangan kapal CPM

\subsection{Tahapan Penelitian}

Untuk mengetahui penyebab keretakan pelat zona lambung kapal fiber glass di bawah garis air, dibuatkan tahapan penelitian sesuai alir diagram berikut:

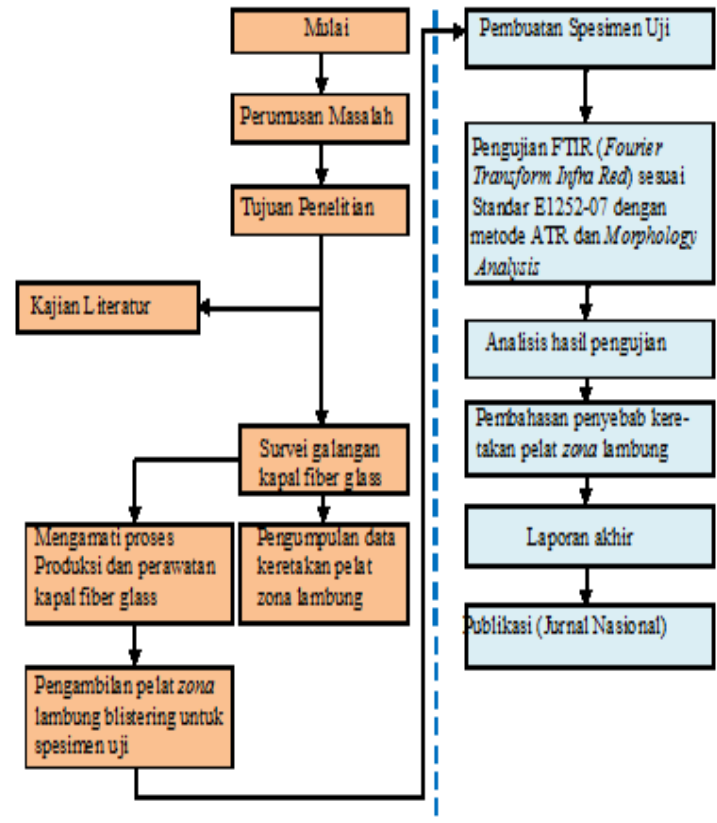

Gambar 10. Diagram alir penelitian

\subsection{Bahan dan Alat}

a. Bahan

Bahan fiber glass yang diperlukan untuk laminasi pelat pelat zona lambung sesuai desain, antara lain: Mirror glaze, Gelcoat, Choped Strand Mat 300 dan 450, Woven Roving 600, Resin polyester dan katalis.

\section{b. Alat}

Peralatan yang digunakan untuk pengambilan spesimen pelat uji antara lain: pensil/spidol, masker kain, sarung tangan, penggaris/mistar baja, jangka sorong dan batu gurinda.

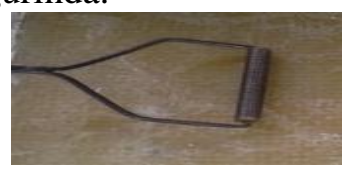

Roll baja

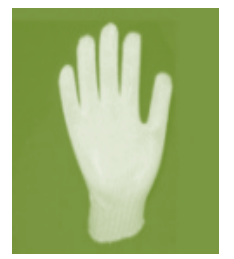

Sarung tangan

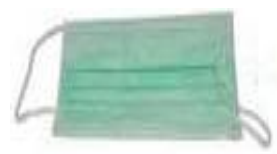

Masker kain

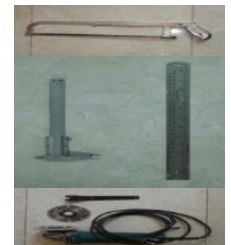

Penggaris, jangka sorong dan mesin gurinda potong

\subsection{Survei ke Galangan Kapal}

Survei ke galangan kapal fiber glass untuk menunjang kegiatan penelitian meliputi antara lain:

a. Mengikuti dan mengamati proses produksi dan perawatan kapal fiber glass. 
b. Dokumentasi dan mengamati kondisi blistering dan visual keretakan pelat zona lambung kapal fiber glass

\subsection{Pembuatan Spesimen Uji}

Pembuatan spesimen uji yang terdiri dari pelat zona lambung bangunan kapal, dilaminasi dengan jumlah layer disesuaikan dengan desain dan pengambilan pelat zona lambung di bawah garis air yang terdapat blistering (lepuh), dimana masing-masing dibentuk sesuai ukuran 150 × 100 x $7 \mathrm{~mm}$, sebagaimana yang diperlihatkan pada gambar 11.
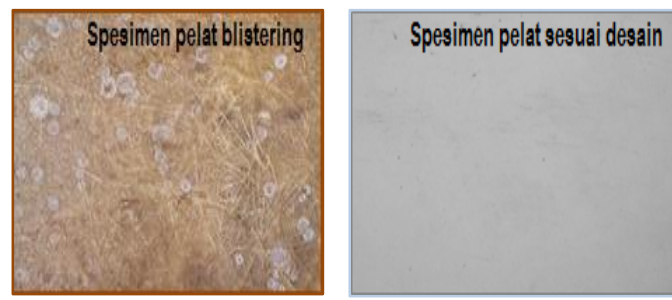

Gambar 11.Spesimen pelat blister dan pelat asli (sesuai desain)

\subsection{Pengujian FTIR dan Morphology \\ Analysis}

Pengujian spesimen pelat zona lambung kapal masing-masing spesimen pelat yang telah mengalami blister dan spesimen pelat yang dilaminasi sesuai desain, dilakukan di laboratorium Sentra Teknologi Polimer (STP) - BPPT Gedung 460 Kawasan PUSPIPTEK Tangerang Selatan - Provinsi Banten yang telah terakreditasi ISO 9091 oleh CERT sebagai laboratorium pengujian polimer.

Pengujian dilaksanakan pada tanggal 01 09 Agustus 2016 berupa pengujian FTIR mircoscope menggunakan metode ATR (Attenuated Total Reflectance) sesuai standar uji ASTM E 1252-07 dan Morphology Analysis menggunakan digital microscope dengan peralatan mesin uji sesuai gambar 12 .
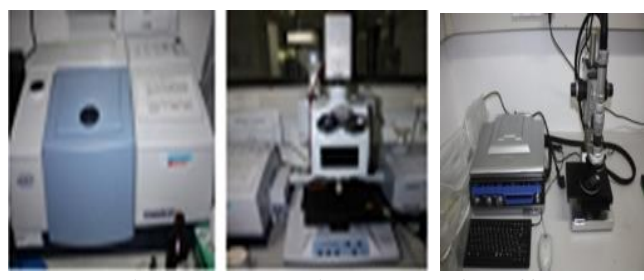

Gambar 12. Peralatan mesin uji FTIR dan Digital mircoscope

\subsection{Parameter dan Kondisi Uji}

Parameter dan kondisi uji spesimen pelat zona lambung fiber glass untuk analisis gugus fungsi dengan FTIR dan morphologi analysis dengan digital microscope sebagaimana diperlihatkan pada tabel. 1

Tabel.1 Parameter dan Kondisi Uji

\begin{tabular}{|c|c|c|c|}
\hline $\begin{array}{c}\text { Jenis } \\
\text { Pengujian } \\
\end{array}$ & \multicolumn{2}{|c|}{ Parameter Uji } & Peralatan Uji \\
\hline \multirow{2}{*}{$\begin{array}{l}\text { Analisa Gugus } \\
\text { Fungsi dengan } \\
\text { FTIR }\end{array}$} & Preparasi & Cutting & \multirow{2}{*}{$\begin{array}{l}\text { Tensor } 27 \\
\text { coupled with } \\
\text { Hyperion } \\
\text { 2000 FTIR }\end{array}$} \\
\hline & $\begin{array}{l}\text { Metode } \\
\text { objective }\end{array}$ & ATR & \\
\hline $\begin{array}{l}\text { Analisa } \\
\text { Morfologi } \\
\text { dengan Digital } \\
\text { Microscope }\end{array}$ & Pembesaran & $\begin{array}{l}50 X, 150 X \\
\text { dan } 350 X\end{array}$ & $\begin{array}{l}\text { Digital } \\
\text { Microscope } \\
\text { Hirox KH } \\
7700\end{array}$ \\
\hline
\end{tabular}

\section{HASIL DAN PEMBAHASAN}

\subsection{Hasil pengamatan di galangan kapal}

Proses produksi dan pemeliharaan/ perawatan blistering zona lambung kapal fiber glass, sebagaimana yang di perlihatkan pada gambar 13 dan Gambar 14.

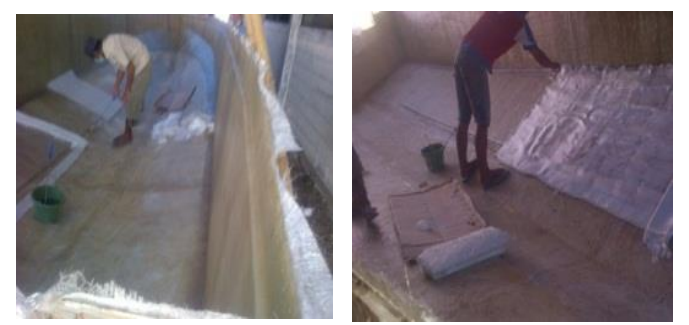

Gambar 13. Proses produksi kapal fiber glass

Dalam hal ini, proses laminasi serat penguat fiber glass Choped Strand Mat dan Woven Roving dengan resin polyester sebagai media pengikat dilakukan secara manual menggunakan kuas tangan dan kuas roll bulu (hand lay up) serta dilakukan di areal terbuka.
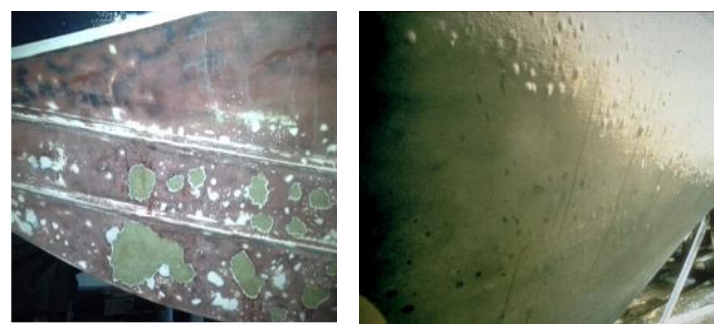

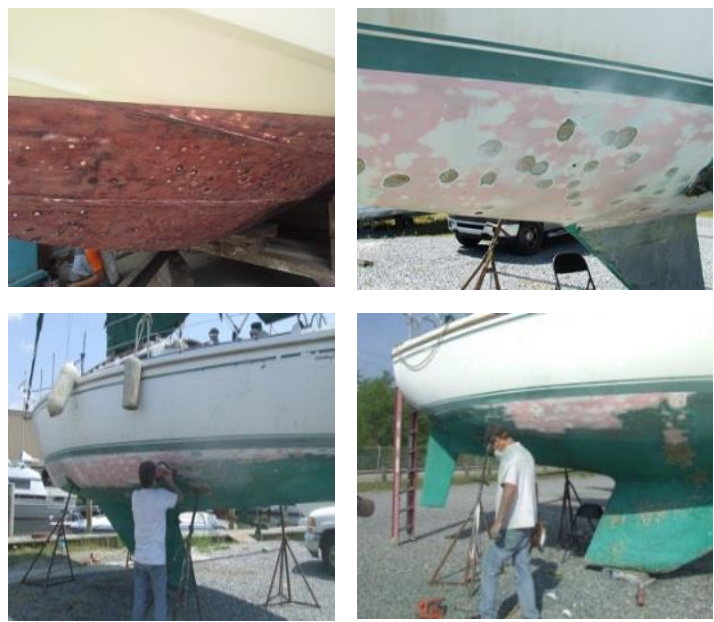

Gambar 13. Kondisi blistering dan perawatan zona lambung kapal fiber glass

Dalam hal ini zona lambung kapal yang mengalami blistering (lepuh) dibersihkan, di wire brush, bagian yang mengalami pitting defect didempul dan digrinding/dihaluskan kemudian dilakukan gelcoat painting. Galangan kapal fiber glass tidak ada yang melakukan pengukuran kelembaban pada zona lambung yang mengalami blistering.

\subsection{Hasil Pengujian FTIR dan Morphology Analysis}

Hasil pengujian spesimen pelat zona lambung blister bercak putih, blister non bercak, dan pelat asli dengan menggunakan FTIR dan Morphology Analysis dapat dijelaskan sebagai berikut:

\section{1). Hasil pengujian FTIR}

Hasil pengujian FTIR berupa identifikasi intensitas bilangan gelombang spesimen pelat zona lambung blister bercak putih, blister non bercak, dan pelat asli sesuai tabel 2. dengan bentuk spektrum sesuai lampiran $1 \mathrm{~s} / \mathrm{d} 3$ yang mengacu pada referensi hummel no. 5430 unsaturated polyester resin based on phtalate maleate polyester (Roskydal 550) sesuai lampiran 4.
Tabel.2 Hasil analisis gugus fungsi dengan FTIR

\begin{tabular}{|c|c|c|}
\hline \multicolumn{2}{|c|}{ Bilangan Gelombang $\left(\mathrm{cm}^{-1}\right)$} & \multirow{2}{*}{ Keterangan } \\
\hline Plat Asli & $\begin{array}{l}\text { Plat Blister } \\
\text { (non bercak) }\end{array}$ & \\
\hline$(3061,3028)$ & - & $\mathrm{C}-\mathrm{H}$ olefin \\
\hline$(2924,2853)$ & $(2924,2854)$ & $\mathrm{CH} 2 / \mathrm{CH} 3$ alifatik \\
\hline 1724 & 1722 & $\mathrm{C}=\mathrm{O}$ \\
\hline- & 1634 & $\begin{array}{l}\mathrm{C}=\mathrm{C} \text { atau } \mathrm{C}=\mathrm{O} \\
\text { amida }\end{array}$ \\
\hline$(605,1586)$ & 1579 & $\mathrm{C}=\mathrm{C}$ aromatik \\
\hline 1495 & 1493 & $\mathrm{C}=\mathrm{C}$ aromatik \\
\hline 1452 & 1452 & $\mathrm{CH}_{2}$ \\
\hline 1379 & 1381 & $\mathrm{CH}_{3}$ \\
\hline 1289 & - & $\begin{array}{l}\text { Ar-O atau C-N atau } \\
\text { C-O-C atau C-H }\end{array}$ \\
\hline 1236 & 1263 & $\mathrm{C}-\mathrm{O}$ \\
\hline 1154 & - & $\mathrm{C}-\mathrm{O}-\mathrm{C}$ \\
\hline \multirow[t]{2}{*}{1072} & - & $\mathrm{C}-\mathrm{O}-\mathrm{C}$ \\
\hline & 1034 & $\mathrm{C}-\mathrm{O}-\mathrm{C}$ \\
\hline \multirow[t]{2}{*}{1005} & - & $\mathrm{CH}=\mathrm{CH}_{2}$ \\
\hline & 913 & $\mathrm{CH}=\mathrm{CH}_{2}$ \\
\hline 832 & - & $=\mathrm{C}-\mathrm{H}$ \\
\hline \multirow[t]{2}{*}{760} & - & $\begin{array}{l}\text { Substitusi cincin } \\
\text { aromatik (mono- } \\
\text { substitusi atau di } \\
\text { substitusi) }\end{array}$ \\
\hline & 743 & $\begin{array}{l}\text { Substitusi cincin } \\
\text { aromatik (disubsti- } \\
\text { tusi) }\end{array}$ \\
\hline 733 & - & $\begin{array}{l}\text { Substitusi cincin } \\
\text { aromatik (mono- } \\
\text { substitusi) }\end{array}$ \\
\hline 701 & 699 & $\mathrm{C}-\mathrm{H}$ aromatik \\
\hline \multirow[t]{5}{*}{649} & - & $\begin{array}{l}\mathrm{O}-\mathrm{C}=\mathrm{O} \text { atau } \mathrm{C}-\mathrm{OH} \\
\text { atau C-C-CHO }\end{array}$ \\
\hline & (bercak putih) & \\
\hline & $(1395,874,713)$ & $\begin{array}{l}\text { Calcium carbonate } \\
\text { (CaCO3), referensi } \\
\text { Hummel no. } 5430\end{array}$ \\
\hline & $(1795,1139,1084)$ & $\mathrm{C}-\mathrm{O}$ \\
\hline & 1649 & $\mathrm{C}=\mathrm{C}$ \\
\hline
\end{tabular}

\section{2).Hasil pengujian morphology analysis}

Hasil pengujian morphology analysis spesimen pelat zona lambung blister bercak putih, blister non bercak, dan pelat asli sebagaimana yang diperlihatkan pada tabel. 3 yakni melakukan pengamatan mikro struktur serat penguat fiber glass pada peralatan digital microscope dilakukan dengan pembesaran 50X, 150X dan 500X sebagaimana yang diperlihatkan pada gambar 15, gambar 16 dan gambar 17 
Tabel. 3 Hasil analisis gugus fungsi dengan morphology

\begin{tabular}{|c|c|c|c|}
\hline \multirow[b]{2}{*}{ No } & \multirow[b]{2}{*}{ Jenis Uji } & \multicolumn{2}{|c|}{ Hasil } \\
\hline & & $\begin{array}{c}\text { Analisis } \\
\text { Gugus Fungsi }\end{array}$ & $\begin{array}{c}\text { Analisis } \\
\text { Morpholoy }\end{array}$ \\
\hline 1. & $\begin{array}{l}\text { Sampel } \\
\text { Pelat Asli }\end{array}$ & $\begin{array}{l}\text { Aromatik polyester } \\
\text { resin atau polyester } \\
\text { resin dengan gugus } \\
\text { aromatik }\end{array}$ & Halus \\
\hline 2. & $\begin{array}{l}\text { Sampel } \\
\text { Pelat Blister } \\
\text { Non Bercak }\end{array}$ & $\begin{array}{l}\text { Aromatik polyester } \\
\text { resin atau polyester } \\
\text { resin dengan gugus } \\
\text { aromatik }\end{array}$ & $\begin{array}{l}\text { Kasar, } \\
\text { permukaan } \\
\text { tanpak } \\
\text { mmengalami } \\
\text { kerusakan }\end{array}$ \\
\hline 3. & \begin{tabular}{|l|} 
Sampel \\
Pelat Blister \\
Bercak \\
Putih
\end{tabular} & $\begin{array}{l}\text { Calcium carbonate } \\
(\mathrm{CaCO} 3)\end{array}$ & $\begin{array}{l}\text { Kasar, } \\
\text { permukaan } \\
\text { tanpak } \\
\text { mengalami } \\
\text { kerusakan/ } \\
\text { terdapat rongga }\end{array}$ \\
\hline
\end{tabular}

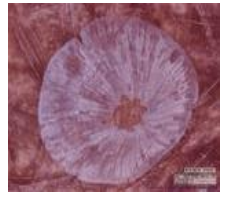

(a)

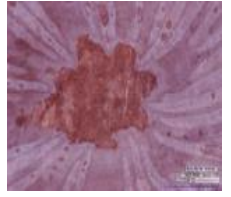

(b)

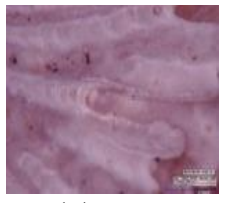

(c)
Gambar 14. Morphology sampel pelat blister bercak putih dengan perbesaran 50X (a), 150X (b) dan $350 X$ (c)

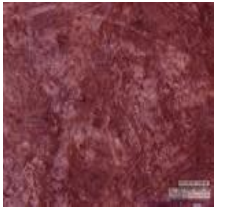

(a)

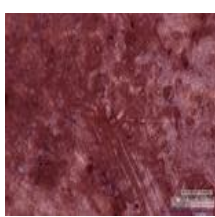

(b)

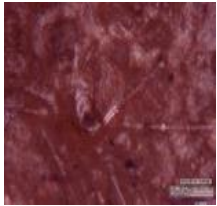

(c)
Gambar 15. Morphology sampel plat blister non bercak dengan perbesaran 50X (a), 150X (b) dan $350 \mathrm{X}$ (c)

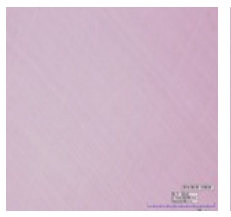

(a)

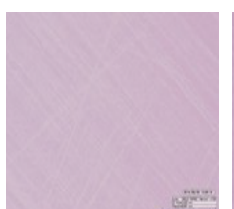

(b)

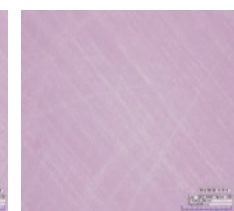

(c)
Gambar 2. Morphology sampel plat asli dengan Perbesaran 50X (a), $150 \mathrm{X}$ (b) dan 350X (c)

\section{3). Hasil analisis keretakan pelat zona lambung}

Blistering (lepuh) yang menimbulkan pitting defect pada zona lambung kapal fiber glass adalah sebagai akibat dari proses produksi (laminasi serat penguat) dilakukan secara manual diareal terbuka. Disisi lain perawatan/pemeliharaan pitting defect blistering dilakukan dengan menutupi pitting defect dengan dempul, diratakan/ dihaluskan dan gelcoat painting.

Sesuai hasil pengujian FTIR (Fourier Transform Infra Red), terdapat perbedaan gugus fungsi pada sampel plat asli dan plat blister non bercak terlihat pada puncak 1722 $\mathrm{cm}^{-1}$ yang merupakan puncak untuk gugus $\mathrm{C}=\mathrm{O}$ (karboksil), di mana pada sample plat blister non bercak puncak tersebut mengalami penurunan intensitas dibandingkan gugus karboksil pada sampel plat asli. Selain itu terdapat puncak tambahan pada sampel plat blister non bercak pada bilangan gelombang $1634 \mathrm{~cm}^{-1}$ yang merupakan gugus $\mathrm{C}=\mathrm{C}, 1263$ $\mathrm{cm}^{-1}$ yang merupakan gugus $\mathrm{C}-\mathrm{O}$ dan pada bilangan gelombang $1034 \mathrm{~cm}^{-1}$ yang merupakan puncak untuk gugus fungsi $\mathrm{C}(\mathrm{sp} 3)$ O. Perubahan puncak penurunan intensitas bilangan gelombang disebabkan karena reaksi hidrolisa terhadap gugus karboksil acrylate yang dapat membentuk senyawa karboksil lainnya sehingga puncak pada $1724 \mathrm{~cm}^{-1}$ mengalami pergeseran dan muncul pada daerah puncak sekitar $1722 \mathrm{~cm}^{-1}$.

Sesuai hasil pengujian morphology, terlihat perbedaan signifikan pada permukaan sampel, dimana permukaan plat asli tampak sangat halus, sementara permukaan plat blister baik pada bagian bercak maupun non bercak sangat kasar dan tampak mengalami perubahan kerusakan yang signifikan dan terlihat terdapat rongga dalam serat penguat.

Kondisi ini mengindikasikan bahwa pelat zona lambung yang mengalami blistering telah terjadi peristiwa osmosis (peristiwa dimana terjadi penyerapan air laut kedalam serat penguat sehingga menyebabkan kandungan air dalam serat penguat menjadi tinggi yang kemudian akan membuat kerapuhan serat penguat dan hal ini yang akan menyebabkan pelat zona lambung dalam waktu tertentu (2 $\mathrm{s} / \mathrm{d}$ 3) tahun[4] mengalami kerusakan/keretakan sebagaimana yang diperlihatkan pada gambar 17. jika terjadi benturan dengan gelombang laut atau objek lain. 


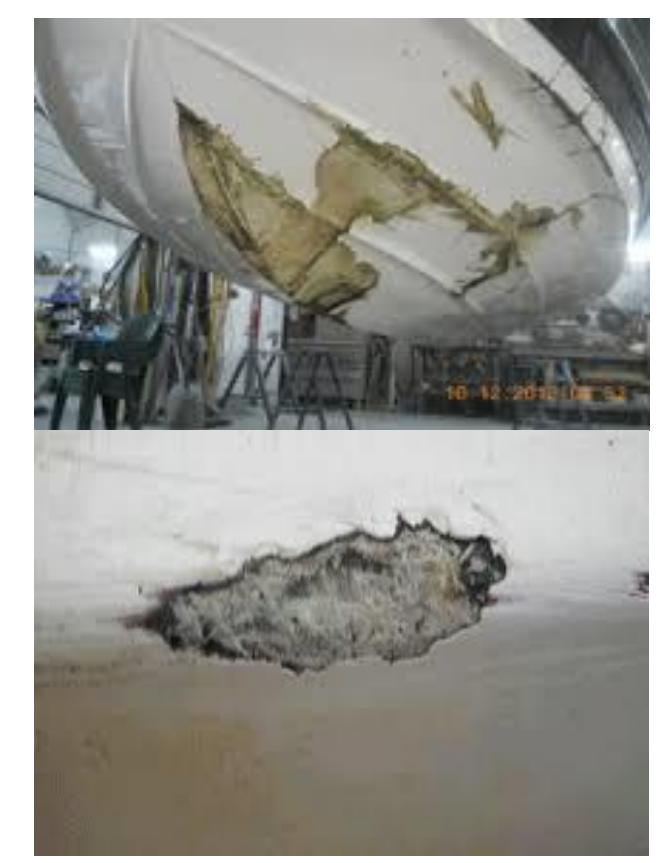

Gambar 16. Visual kerusakan/keretakan pelat zona lambung

\section{KESIMPULAN DAN SARAN \\ 5.1. Kesimpulan}

a. Produksi kapal fiber glass (laminasi serat penguat) dilakukan secara manual diareal terbuka, berpeluang terjadinga air trap dan menimbulkan blistering.

b. Perawatan/pemeliharaan pitting defect blistering yang dilakukan di galangan kapal, menutupi pitting defect dengan dempul, diratakan/dihaluskan dan gelcoat painting. Tidak melakukan pengukuran kandungan air serat penguat sehingga hal ini berpeluang terjadi kegagalan dalam perawatan zona lambung kapal fiber glass.

c. Terdapat penurunan gugus fungsi pada sampel plat asli dan plat blister non bercak terlihat pada puncak $1724 \mathrm{~cm}^{-1}$ menjadi 1722 $\mathrm{cm}^{-1}$ yang merupakan puncak untuk gugus $\mathrm{C}=\mathrm{O}$ (karboksil), Selain itu terdapat puncak tambahan pada sampel plat blister non bercak pada bilangan gelombang $1634 \mathrm{~cm}^{-1}$ yang merupakan gugus $\mathrm{C}=\mathrm{C}, 1263 \mathrm{~cm}^{-1}$ yang merupakan gugus $\mathrm{C}-\mathrm{O}$ dan pada bilangan gelombang $1034 \mathrm{~cm}^{-1}$ yang merupakan puncak untuk gugus fungsi $\mathrm{C}(\mathrm{sp} 3)-\mathrm{O}$. Hal ini disebabkan karena adanya reaksi hidrolisa terhadap gugus karboksil acrylate yang dapat membentuk senyawa karboksil lainnya.

d. Terdapat perbedaan signifikan pada permukaan sampel, dimana permukaan plat asli tampak sangat halus, sementara permukaan plat blister baik pada bagian bercak maupun non bercak sangat kasar dan tampak mengalami perubahan kerusakan yang signifikan dan terlihat terdapat rongga dalam serat penguat.

e. Pelat zona lambung yang mengalami blistering telah terjadi peristiwa osmosis sehingga menyebabkan kandungan air dalam serat penguat menjadi tinggi yang kemudian akan membuat kerapuhan serat penguat, dan dalam waktu tertentu (2 s/d 3) tahun[4] pelat zona lambung dapat mengalami kerusakan/keretakan jika terjadi benturan dengan gelombang laut atau objek lain.

\subsection{Saran}

a. Untuk meminimalisir air trap yang dapat mengakibatkan terjadinya blistering maka dalam proses produksi kapal fiber glass, selain menggunakan kuas tangan dan kuas roll bulu untuk laminasi serat penguat agar menggunakan kuas roll baja untuk menekan serat penguat secara utuh dan sempurna.

b. Untuk menghindari kerusakan/keretakan pelat fiber glass, lakukan pengukuran kandungan air pada areal blistering pelat zona lambung. Jika kandungan air serat penguat fiber glass telah melebihi ambang batas (1012) $\% \mathrm{H}_{2} \mathrm{O}$ maka lakukan tindakan treatment berupa crooping atau penggantian pelat sesuai ketentuan Badan Klasifikasi.

c. Jika galangan kapal tidak melakukan pengukuran kandungan air, maka pitting defect blistering sebelum didempul/ ditutupi dibiarkan dahulu \pm selama 1 (satu) minggu agar keberadaan air dalam serat penguat akibat dari peristiwa osmosis dapat keluar yang kemudian dibantu dengan proses pemanasan zona lambung dengan menggunakan lampu sorot.

\section{DAFTAR PUSTAKA}

[1] Buana Ma'ruf, A Study on Standardization of Fiberglass Ship's Hull Lamination Constructio - Maret, 2011.

[2] Biro Klasifikasi Indonesia (BKI), Rules for Non Metallic Materials Part 1, Edisi 2006

[3] David Fecko, Advanced Glassfiber Yarns LLC, Huntingdon, Optimized Racing Boat Design Using Uniquehigh Strenth Fiberglass, 2002.

[4] Nigel Clegg, A short Guide to Osmosis and its Treatment, Januari 2011. 
[5] S. Alameda St. Compton, Fiberglass and Composite Material Design Guide, Januari, 2011.

[6] U.S.Environmental Protection Agency Office of Air Quality Planning and Standards, Control Techniques Guidelines for Fiberglass Boat Manufacturing Materials-September, 2008.

[7] West System, Inc., Bay City, Michigan, USA -Fiberglass Boad Repair and Maintenance, 14th EditionDecember,2006.

[8] Jurnal Bina Widya, Majalah Ilmiah UPN "Veteran" Jakarta, Desain Kapal Ikan Sederhana Fiber glass, ISSN 0853-2621, Volume 20 No.3, Nopember 2009.

[9] Jurnal Bina Widya, Majalah Ilmiah UPN "Veteran" Jakarta, Metode Perawatan yang Tepat kapal fiber glass ISSN 08532621, Volume 25 No.2, Mei 2014.

\section{LAMPIRAN}

Lampiran 1. Spektrum FTIR sampel pelat asli

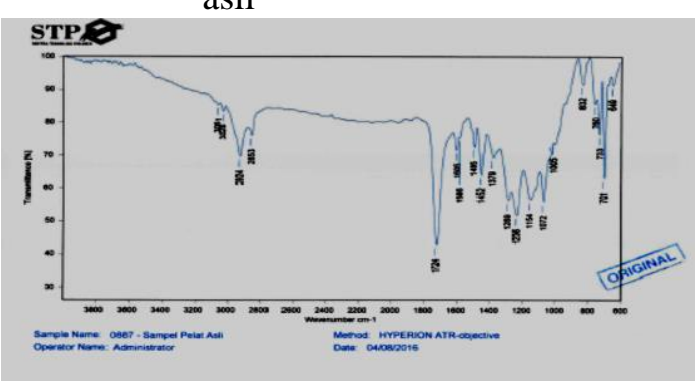

Lampiran 2. Spektrum FTIR sampel pelat blister bercak putih

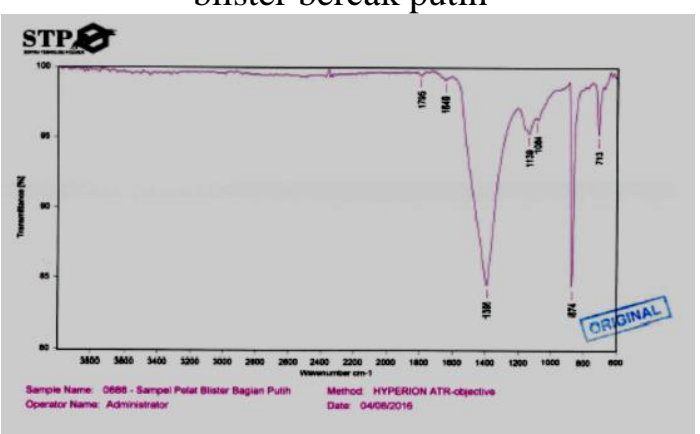

Lampiran 3. Spektrum FTIR sampel pelat blister non bercak (bagian bersih)

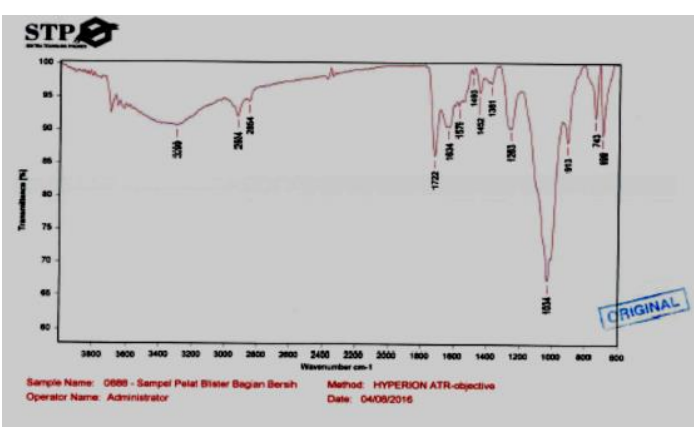

Lampiran 4. Spektrum FTIR referensi hummel No. 5430

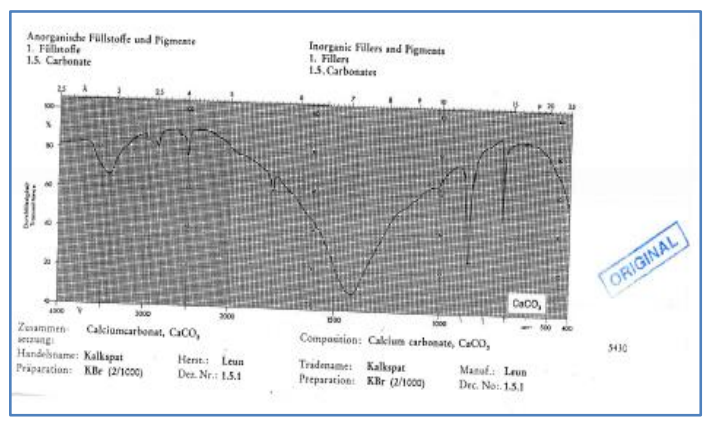

